\title{
Vertical distribution of nonylphenol and nonylphenol ethoxylates in sedimentary core from the Beipaiming Channel, North China
}

\author{
JIN Fen ${ }^{1,2}$, HU Jian-ying ${ }^{2, *}$, YANG Min ${ }^{1}$ \\ 1. State Key Lab of Environmental Aquatic Chemistry, Research Center for Eco-Environmental Sciences, \\ Chinese Academy of Sciences, Beijing 100085, China.E-mail: jinfenbj@gmail.com \\ 2. College of Environmental Science, Peking University, Beijing 100871, China
}

Received 13 March 2006; revised 25 April 2006; accepted 8 May 2006

\begin{abstract}
The vertical profiles of nonylphenol (NP) and nonylphenol ethoxylates (NPEOs) were investigated in a sediment core from the Beipaiming Channel, North China using high sensitive LC-MS and GC-MS methods. In this core, relatively high concentrations of NP and NPEOs occurred in the surface sediment $(\leqslant 40 \mathrm{~cm})$, with the maximum value of NP and NPEOs reaching 3539 and 12735 $\mathrm{ng} / \mathrm{g}$, respectively, whereas, no NP or NPEOs were detected in deeper sediments $(>40 \mathrm{~cm})$. The high concentrations of NP and NPEOs in the surface layers suggested recent inputs in this area. NPEOs with short ethoxy chains $\left(\mathrm{NP}_{n} \mathrm{EO}, n=0-3\right)$ were dominant in the NPEO mixture with percentages from $54 \%$ to $78 \%$, which were similar to the distribution of homolog NPEO in effluents from nearby sewage treatment plants (STPs), indicating that the channel received the effluents from these STPs. The sewage treatment ratio was quite similar to that found in North America before the 1980s. Finally, the concentrations of NP and NPEOs were related to the total organic carbon (TOC) $(p<0.001)$, suggesting that TOC was an important factor for vertical distribution of NPEOs and NP from the Beipaiming Channel.
\end{abstract}

Key words: nonylphenol; nonylphenol ethoxylates; sediment core; Bohai Bay

\section{Introduction}

Nonylphenol ethoxylates (NPEOs) are important nonionic surfactants widely used in industrial and consumer products as cleaning agents and emulsifiers (Warhurst, 1995; Naylor, 1996). A typical NPEO surfactant formulation is comprised of NP with an average of 10 ethoxy units, usually within the range of 1 to 20 ethoxy units. Biodegradation of NPEOs during wastewater treatment processes can result in shortening of the ethoxy chain and subsequent degradation to NP under anaerobic conditions (Ahel and Giger, 1993; Ahel et al., 1994a, b; Giger and Brunner, 1984). Considering the estrogenicity and the large production volumes of NPEOs and NP (Servos, 1999; Jobling et al., 1996; Sharpe et al., 1995; White et al., 1994), there is an increasing concern about the environmental occurrence and fate of NPEOs and their biodegradation intermediates.

Many studies have shown that NP and NPEOs are ubiquitous in aquatic environments (Maruyama et al., 2000; Kannan et al., 2003), as exemplified by their occurrence in sediment and fish tissues (Shao et al., 2005; Keith et al., 2001; Lye et al., 2001; Rice et al., 2003; Ferrara et $a l ., 2001)$. It has been found that NPEOs and their neutral

Project supported by the National Basic Research Program of China (No. 2007CB407304, 2003CB415004) and the National Natural Science Foundation of China (No. 20307010). *Corresponding author.

E-mail: hujy@urban.pku.edu.cn. metabolites accumulate and persist in sediments, and their half-lives are about 60 years in the stratified sediment (Shang et al., 1999). Thus, the vertical profiles of NP and NPEOs in sediment cores can be used to evaluate their history in local areas as exemplified by the bedded sediment in a sewage-impacted urban estuary (Shang et al., 1999; Ferguson et al., 2003). However, there is insufficient information about the vertical profiles of NPEOs and NP in sedimentary samples, especially in China (Hu et al., 2005).

Bohai Bay is a semi-enclosed shallow water basin located in the north of China. Beipaiming Channel, located on the western shore of Bohai Bay, receives industrial and municipal wastewaters from the Tianjin Economictechnological Development Area (TEDA), which is one of the most industrialized areas and is a probable source of NP and NPEOs entering Bohai Bay.

In a previous study, relatively high concentrations of NPEOs and NP were found in Bohai Bay, which were attributed to high loading of NPEOs from estuaries adjacent to Bohai Bay (Hu et al., 2005). In this article, the vertical profiles of NP and NPEOs in a sedimentary core from Beipaiming Channel were investigated, to determine the input in this area, which will contribute to the evaluation of their loading in Bohai Bay.

\section{Materials and methods}

\subsection{Sediment sampling}


Fig. 1 shows a map indicating the place where a sediment core was taken from, in Beipaiming Channel $\left(39^{\circ} 30^{\prime} \mathrm{N}\right.$, $117^{\circ} 26^{\prime} \mathrm{E}$ ), in November 2001 . The core sample was sliced at $5-\mathrm{cm}$ intervals for up to $145 \mathrm{~cm}$, with a clean stainless steel slicer. Each section was stored at $-20^{\circ} \mathrm{C}$ until analysis.

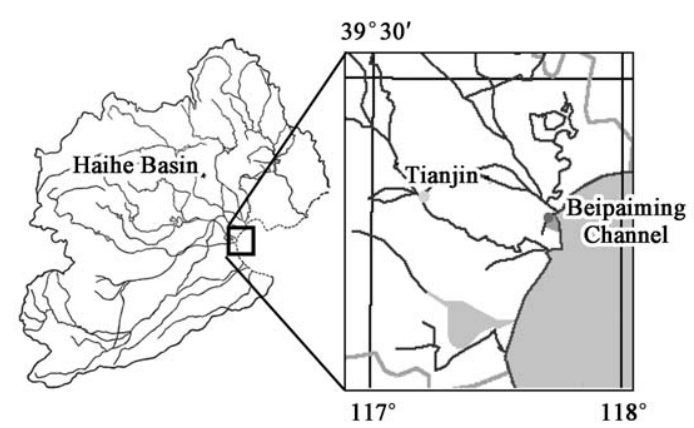

Fig. 1 Location of the sediment core from Beipaiming Channel, China.

\subsection{Chemicals and standards}

NP (technical grade), a mixture of compounds with branched side chains, was purchased from Kanto Chemicals (Tokyo, Japan). Authentic standard nonylphe-

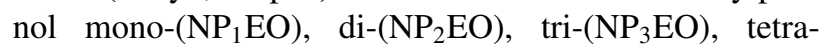
$\left(\mathrm{NP}_{4} \mathrm{EO}\right)$, penta- $\left(\mathrm{NP}_{5} \mathrm{EO}\right)$, and hexaethoxylates $\left(\mathrm{NP}_{6} \mathrm{EO}\right)$ and mixture standard of $\mathrm{NP}_{9} \mathrm{EO}$ (a mixture of NPEOs with an average of $9 \mathrm{EO}$ units) and $\mathrm{NP}_{15} \mathrm{EO}$ (a mixture of NPEOs with an average of $15 \mathrm{EO}$ units) were purchased from Hayashi Pure Chemicals (Tokyo, Japan). Dichloromethane, methanol, acetonitrile, and hexane were HPLC grade (Fisher Chemical Co., China). Ultra pure water was prepared using an Easypure UV Compact Ultrapure System (Fisher Chemical Co., China).

\subsection{Sediment extraction and analysis}

\subsubsection{Extraction}

For Soxhlet extraction, sediment ( $10 \mathrm{~g}$ dw mixed with 20 $\mathrm{g} \mathrm{Na}_{2} \mathrm{SO}_{4}$ ) was transferred to a quartz extraction thimble and extracted with $250 \mathrm{ml}$ of dichloromethane/methanol $(7: 3, \mathrm{v} / \mathrm{v})$ for $24 \mathrm{~h}$. Extracts were passed through 12 $\mathrm{g}$ of $5 \% \mathrm{H}_{2} \mathrm{O}$ deactivated neutral $\mathrm{Al}_{2} \mathrm{O}_{3}$ (200 mesh size, Shanghai Ludu Chemicals, China) packed in a glass column (10 mm i.d.) for cleanup and fractionation. The first fraction, eluted with $30 \mathrm{ml}$ high-purity hexane and $30 \mathrm{ml}$ hexane/dichloromethane $(3: 1, \mathrm{v} / \mathrm{v})$, contained some nonpolar or less polar chemicals. NP and NPEOs were eluted in the second fraction with $30 \mathrm{ml}$ hexane/dichloromethane $(50: 50, \mathrm{v} / \mathrm{v}), 40 \mathrm{ml}$ dichloromethane, $30 \mathrm{ml}$ dichloromethane/methanol $(85: 15, \mathrm{v} / \mathrm{v})$, and 30 $\mathrm{ml}$ dichloromethane/methanol (50:50, v/v). NP, NP $\mathrm{NO}_{1}$, and $\mathrm{NP}_{2} \mathrm{EO}$ were determined by gas chromatographymass spectrometry (GC-MS). NPEOs were analyzed using liquid chromatography-electrospray ionization-mass spectrometry (LC-ESI-MS) (Shao et al., 2002).

\subsubsection{Chemical analysis}

GC-MS analysis was performed with a Hewlett-Packard
5890 gas chromatograph connected to a Hewlett-Packard 5971 mass spectrometer. The mass spectrometer was operated in the electron impact ionization mode with an ionizing energy of $70 \mathrm{eV}$. The injector temperature was maintained at $250^{\circ} \mathrm{C}$, and the detector source temperature was kept at $280^{\circ} \mathrm{C}$. A DB-5MS capillary column $(30 \mathrm{~m}$ $0.25 \mathrm{~mm}$ i.d. with a film thickness of $0.25 \mu \mathrm{m}$ ) was used for $\mathrm{NP}, \mathrm{NP}_{1} \mathrm{EO}$, and $\mathrm{NP}_{2} \mathrm{EO}$ analysis, programmed to progress from $50^{\circ} \mathrm{C}(2 \mathrm{~min})$ to $200^{\circ} \mathrm{C}$ at $20^{\circ} \mathrm{C} / \mathrm{min}(2 \mathrm{~min})$, and to $260^{\circ} \mathrm{C}$ at $5^{\circ} \mathrm{C} / \mathrm{min}$, and then to $280^{\circ} \mathrm{C}$ at $20^{\circ} \mathrm{C} / \mathrm{min}$ (5 min). The injection volume was $2 \mu \mathrm{l}$, and a splitless mode was used. Quantitative analysis was performed using the selected ion monitoring mode, and the fragment ions were selected according to the most abundant ions in each oligomer.

NPEOs with $n>2$ were detected with the help of LCESI-MS being performed using an Alliance 2690 HPLC (Waters, USA) equipped with a quaternary gradient pump, an autosampler with a $100-\mathrm{ml}$ injection loop, a $\mathrm{C}_{18}$ precolumn $(2.1 \mathrm{~mm}$ in ID $\times 50 \mathrm{~mm}, 3 \mu \mathrm{m}$ Capcell Pak, Shiseido, Japan), and a silica analytical column $(2.1 \mathrm{~mm}$ in ID $\times 150$ $\mathrm{mm}, 3 \mu \mathrm{m}$ Spherisorb SW3, Waters). The flow was kept at $0.1 \mathrm{ml} / \mathrm{min}$ for $1 \mathrm{~min}$ with $100 \%$ acetonitrile, and then increased linearly to $0.35 \mathrm{ml} / \mathrm{min}$ over $34 \mathrm{~min}$. The solvent composition was changed linearly to $75 \%$ acetonitrile $/ 25 \%$ water over $35 \mathrm{~min}$, then linearly to $100 \%$ acetonitrile over $5 \mathrm{~min}$, while the flow was kept at $0.35 \mathrm{ml} / \mathrm{min}$ for $10 \mathrm{~min}$. The flow was then held at $0.1 \mathrm{ml} / \mathrm{min}$ for $40 \mathrm{~min}$ to equilibrate the columns before the next injection. A platform ZMD single quadrupole mass spectrometer (Micromass, Manchester, UK) was used, with a Z-Spray ion source, fitted with a pneumatically assisted electro-spray probe. NPEOs were detected in the positive mode, and typical ion source parameters were used as follows: ESI capillary voltage at $3.5 \mathrm{kV}$; extractor voltage at $5 \mathrm{~V}$; source block temperature at $120^{\circ} \mathrm{C}$; desolvation temperature at $180^{\circ} \mathrm{C}$; ion energy at $0.8 \mathrm{~V}$; multiplier voltage at $650 \mathrm{~V}$; nitrogen was used as a desolvation gas, with a flow rate between 270 and $350 \mathrm{~L} / \mathrm{h}$, and cone gas at a flow rate of 70 to $100 \mathrm{~L} / \mathrm{h}$. The cone voltage was ramped from 25 to $70 \mathrm{~V}$ with the full scan mass ranging from 280 to 1500 and with a scan time of $1.2 \mathrm{~s}$. Masslynx 3.4 workstation software was used for data processing. Quantitative analysis was performed using the ions of $\left[\mathrm{M}+\mathrm{Na}^{+}\right]\left(\mathrm{Na}^{+}\right.$adducted molecules with NPEOs). The procedure described above was validated for recoveries (ranging from $92 \%$ to $105 \%$ for NPEOs and $80 \%$ for NP). The precision was estimated at better than $20 \%$ based on the analysis of three replicate samples collected from the Beipaiming Channel.

\subsection{Total organic carbon}

Total organic carbon (TOC) was measured by the hightemperature combustion method. Dry sediment (about 5 $\mathrm{mg})$ was put into small precombusted $\left(600^{\circ} \mathrm{C}, 4 \mathrm{~h}\right)$ quartz sample boats. Phosphoric acid (20\%) was added to remove inorganic carbon from the samples. Finally, the samples were analyzed using a TOC Analyzer (Apollo 9000, Tekmar-Dohrmann, USA). 


\section{Results and discussion}

\subsection{Vertical profiles of NP and NPEOs in a sedimentary core from Beipaiming Channel}

Fig. 2 shows the vertical profiles of NP and NPEOs in the sediment core. NP concentrations ranged from no detection to $3539 \mathrm{ng} / \mathrm{g}$ dry weight (dw), which is higher than those reported in the Cuyahoga River (Rice et al., 2003) and Nanpaiwu River (Hu et al., 2005). It was found that although the NP concentration was less than the undetectable level at the depth of 145 to $40 \mathrm{~cm}$, within the surface layer $(\leqslant 40 \mathrm{~cm})$ the concentration was from 579 to $3539 \mathrm{ng} / \mathrm{g} \mathrm{dw}$. The maximum value occurred at 25$30 \mathrm{~cm}$ followed by $3209 \mathrm{ng} / \mathrm{g} \mathrm{dw}$ at a depth of $5-10 \mathrm{~cm}$. This profile was similar to that in a sediment core from Jamaica Bay (Ferguson et al., 2003). Not surprisingly, the concentration profile of NPEOs in the core also showed a distribution similar to that of NP in the same samples (Fig.2b), as also the NPEOs were only detected within $40 \mathrm{~cm}$ from the surface sediment, and the total NPEO concentration ranged from 736 to $12735 \mathrm{ng} / \mathrm{g} \mathrm{dw}$. The maximum concentration of NPEOs occurred in the 0-5 $\mathrm{cm}$ layer with the maximum of $12735 \mathrm{ng} / \mathrm{g} \mathrm{dw}$, which was followed by $4446 \mathrm{ng} / \mathrm{g} \mathrm{dw}$ at the depth of $25-30 \mathrm{~cm}$. The above vertical profiles for NPEOs and NP reflected the recently increased inputs of NPEOs in this area. The fact that there have been many new electronic and chemical corporations established in the TEDA since 1984, and also the fact that the Beipaiming Channel was dug in 1985, to receive industrial and domestic wastewater, is strong evidence that NP and NPEOs could only be detected in the surface sediment $(<40 \mathrm{~cm})$.

Fig. 3 shows the relationship between the concentration of NPEOs and NP in the sediment. The NP concentrations in the sediment appeared to increase with an
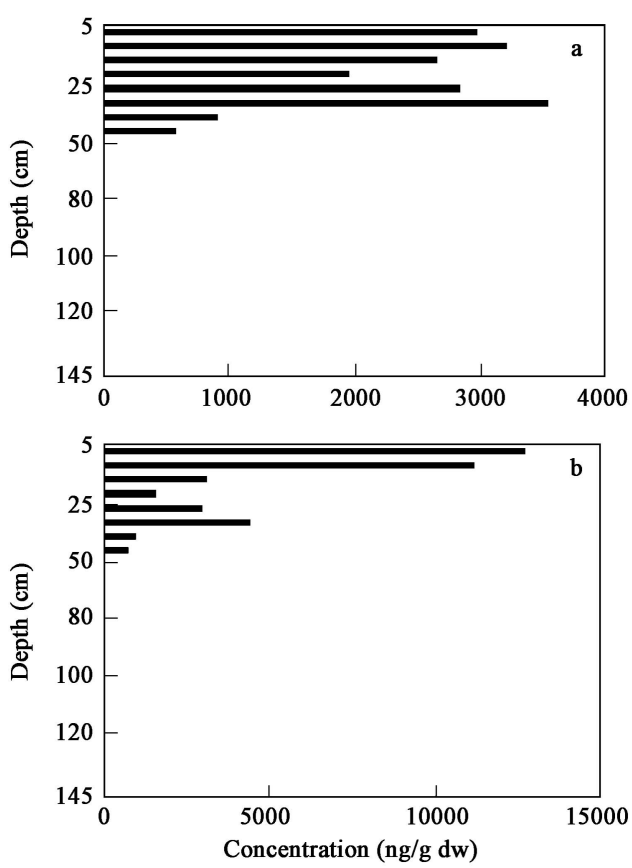

Fig. 2 Concentration profiles of NP(a) and NPEOs(b) in sedimentary core from Beipaiming Channel. increase in NPEO concentration in the sediment from the Beipaiming Channel $(p<0.001)$. This result indicates that the occurrence of NP is related to NPEOs. In the previous article, similar results were also found in other sediment core samples from the Nanpaiwu River, another estuary adjacent to Bohai Bay (Hu et al., 2005).

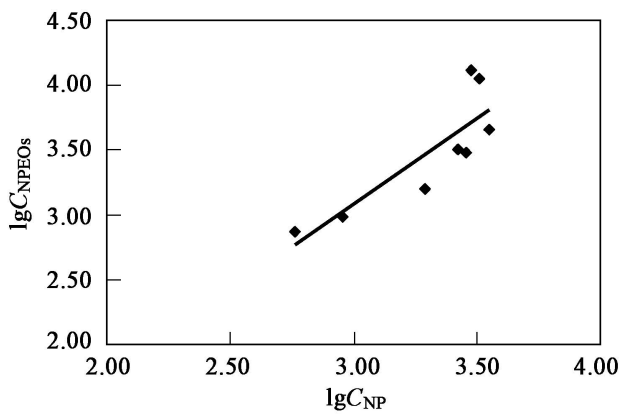

Fig. 3 Relationship between the concentration of NP and NPEOs in the sedimentary core from Beipaiming Channel, China $(p<0.001$, $r^{2}=0.7087$ )

\subsection{Distribution of homolog NPEOs in NPEO mixture}

Nonylphenolic compounds are generally divided into three groups: (a) $\mathrm{NP}$, (b) $\mathrm{NP}_{1} \mathrm{EO}+\mathrm{NP}_{2} \mathrm{EO}$, and (c) $\mathrm{NP}_{3} \mathrm{EO}-\mathrm{NP}_{18} \mathrm{EO}$. The typical distributions of homolog $\mathrm{NP}_{n} \mathrm{EO}(n=0-8)$ in the NPEO mixtures at different depths are shown in Fig.4. In contrast to the commercial mixture, the contributions of $\mathrm{NP}_{1} \mathrm{EO}, \mathrm{NP}_{2} \mathrm{EO}$, and $\mathrm{NP}$ are significantly higher than those in the long ethoxy chain $\mathrm{NP}_{n} \mathrm{EO}(n=3-18)$ in this sedimentary core. As shown in Fig. $4 \mathrm{a}, \mathrm{NP}_{1} \mathrm{EO}$ and $\mathrm{NP}_{2} \mathrm{EO}$ in the $0-5 \mathrm{~cm}$ layer were the prominent components of the total NPEO mixture (48\%), and NP also significantly contributed $19 \%$. However, in the deeper sediments $(20-25 \mathrm{~cm})$, a considerable contribution

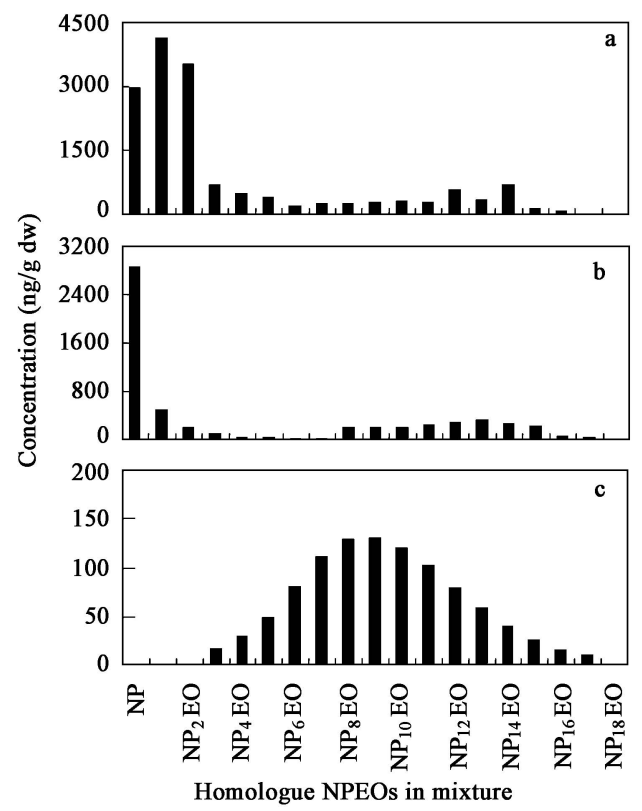

Fig. 4 NPEO homolog distribution at different depths from the Beipaiming Channel. (a) 0-5 cm; (b) 20-25 cm; (c) commercial NP $\mathrm{EO}$ (1000 $\mathrm{ng} / \mathrm{g})$. 
(49\%) to the total was from NP, which was significantly higher than those of $\mathrm{NP}_{1} \mathrm{EO}(8 \%)$ and $\mathrm{NP}_{2} \mathrm{EO}(3 \%)$ (Fig.4b). Generally, two types of homolog distributions were observed in this core; that is, in the recently deposited sediments $(\leqslant 10 \mathrm{~cm})$, NPEOs were dominated by $\mathrm{NP}_{1} \mathrm{EO}$ and $\mathrm{NP}_{2} \mathrm{EO}$, whereas in the deeper sediments $(>10 \mathrm{~cm})$, an NP-rich NPEO mixture was present.

It is well-known that $\mathrm{NP}_{n} \mathrm{EO}(n=0-2)$ are the predominant metabolites of NPEOs through biodegradation (Ahel and Giger, 1993; Ahel et al., 1994a, b). Therefore, it can be hypothesized that the characteristic distribution dominated by $\mathrm{NP}_{n} \mathrm{EO}(n=0-2)$ in this sedimentary core may be on account of the output from STPs or the biotransformation between the long and short ethoxy chains in the estuarial environment. Ahel et al. (1994a) investigated the patterns of NPEOs in the effluents from 11 different STPs, and found that the NPEO mixtures from 10 STPs were dominated by $\mathrm{NP}_{1} \mathrm{EO}$ and $\mathrm{NP}_{2} \mathrm{EO}$, whereas, $\mathrm{NP}$ dominated that from one STP. Such a difference in NPEO patterns was explained by the different operating conditions of individual STPs (Ahel et al., 1994a). In addition, Ahel et al. (1994b) also reported that the biodegradation efficiency of NPEOs in rivers is much lower than that in STPs. Thus, a similar distribution in those in the effluents of STPs and their persistence in the sediment suggested that NPEOs and NP in the channel would stem from the discharging of sewage effluent from STPs.

The ratio of $\mathrm{NP}_{n} \mathrm{EO}(n=0-3)$ to total NPEOs has been used as a marker for the sewage treatment ratio (Ferguson et al., 2003). To estimate the sewage treatment ratio of NPEOs in this area, the ratio with other countries has been compared. In this core, the ratio of $\mathrm{NP}_{n} \mathrm{EO}(n=0-3)$ to total NPEOs ranges from $54 \%$ to $78 \%$ (Table 1). Although the age of sediments has not been measured in this study, the sediment at $40 \mathrm{~cm}$ corresponds to the one from 1985, when the channel was dug.

Ferguson et al. (2003) reported that the ratio in sedi- ments of Jamaica Bay, North America, was from $86 \%$ to $95 \%$ in the period $1980-1995,77 \%$ to $86 \%$ in the period $1963-1980$, and $43 \%$ to $49 \%$ before 1963 . Compared to the ratio in Jamaica Bay, the sewage treatment ratio in this area is quite near to that in North America before the 1980s. Because of the low sewage treatment ratio, most of the industrial wastewater was discharged into the channel without biological treatment. In fact, although the amount of sewage was $900000 \mathrm{~m}^{3} / \mathrm{d}$, the capacity of the STP was $100000 \mathrm{~m}^{3} / \mathrm{d}$ in this area with the ratio of treatment of $10 \%$.

\subsection{Relationship between TOC and NP, NPEOs in sedi- mentary core}

TOC values of the sedimentary samples varied from $0.93 \%$ to $2.40 \%$. For the sedimentary samples, a relationship between the NP concentration and TOC was plotted in Fig.5a. It was found that the NP concentration increased with increasing TOC in the sedimentary core, and the regression analysis indicated that this correlation was statistically significant $(p<0.001)$. A good correlation was also obtained between the NPEOs concentration and TOC $(p<0.001)$ (Fig.5b). These results indicated that the organic carbon in the sediments was an important factor for vertical distribution of NPEOs and NP from the Beipaiming Channel.

\section{Conclusions}

A relatively high concentration of NP and NPEOs was detected in the surface sediment of a sedimentary core from Beipaiming Channel, suggesting a recent increasing input of these compounds in this area. The vertical distribution of NPEOs was found to be quite similar to that of NP in the same samples, and the significant correlation between the concentration of NPEOs and NP demonstrated that the occurrence of NP is related to that of NPEOs in the sediment from the Beipaiming Channel. The short chain NPEOs dominant in NPEO mixtures in this sedimentary

Table 1 Concentrations (ng/g dw) of NPEOs with EO units ranging from 0 to 18 in sedimentary core from Beipaiming Channel

\begin{tabular}{|c|c|c|c|c|c|c|c|c|c|}
\hline \multirow[t]{2}{*}{ Chemicals } & \multicolumn{9}{|c|}{ Depth $(\mathrm{cm})$} \\
\hline & 5 & 10 & 15 & 20 & 25 & 30 & 35 & 40 & 50 \\
\hline NP & 2976 & 3209 & 2661 & 1951 & 2843 & 3539 & 906 & 579 & ND \\
\hline $\mathrm{NP}_{1} \mathrm{EO}$ & 4126 & 4146 & 404 & 166 & 492 & 1553 & 139 & 97 & ND \\
\hline $\mathrm{NP}_{2} \mathrm{EO}$ & 3516 & 2222 & 271 & 231 & 195 & 1087 & 95 & 32 & ND \\
\hline $\mathrm{NP}_{3} \mathrm{EO}$ & 697 & 697 & 269 & 132 & 109 & 84 & 31 & ND & ND \\
\hline $\mathrm{NP}_{4} \mathrm{EO}$ & 492 & 232 & 128 & 23 & 37 & 145 & 7 & 73 & ND \\
\hline $\mathrm{NP}_{5} \mathrm{EO}$ & 410 & 193 & 107 & 19 & 31 & 121 & 6 & 60 & ND \\
\hline $\mathrm{NP}_{6} \mathrm{EO}$ & 203 & 207 & 102 & 26 & 14 & 106 & 31 & 69 & ND \\
\hline $\mathrm{NP}_{7} \mathrm{EO}$ & 254 & 249 & 116 & 71 & 14 & 126 & 55 & 92 & ND \\
\hline $\mathrm{NP}_{8} \mathrm{EO}$ & 252 & 320 & 203 & 112 & 202 & 184 & 85 & 108 & ND \\
\hline $\mathrm{NP}_{9} \mathrm{EO}$ & 299 & 299 & 210 & 127 & 215 & 204 & 145 & 91 & ND \\
\hline $\mathrm{NP}_{10} \mathrm{EO}$ & 311 & 325 & 231 & 171 & 200 & 211 & 159 & 50 & ND \\
\hline $\mathrm{NP}_{11} \mathrm{EO}$ & 304 & 333 & 180 & 157 & 236 & 140 & 83 & 22 & ND \\
\hline $\mathrm{NP}_{12} \mathrm{EO}$ & 570 & 430 & 217 & 133 & 279 & 129 & 61 & 28 & ND \\
\hline $\mathrm{NP}_{13} \mathrm{EO}$ & 353 & 729 & 319 & 144 & 326 & 166 & 64 & 13 & ND \\
\hline $\mathrm{NP}_{14} \mathrm{EO}$ & 711 & 418 & 192 & 50 & 274 & 120 & 18 & 2 & ND \\
\hline $\mathrm{NP}_{15} \mathrm{EO}$ & 144 & 273 & 138 & 22 & 221 & 50 & 2 & ND & ND \\
\hline $\mathrm{NP}_{16} \mathrm{EO}$ & 83 & 70 & 38 & 4 & 70 & 15 & ND & ND & ND \\
\hline $\mathrm{NP}_{17} \mathrm{EO}$ & 8 & 23 & 15 & 1 & 34 & 4 & ND & ND & ND \\
\hline $\mathrm{NP}_{18} \mathrm{EO}$ & 2 & 2 & 3 & ND & 10 & 1 & ND & ND & ND \\
\hline$R^{*}$ & 0.72 & 0.71 & 0.62 & 0.7 & 0.63 & 0.78 & 0.62 & 0.54 & ND \\
\hline
\end{tabular}

$R=\sum \mathrm{NP}_{n} \mathrm{EO}(0-3) / \sum \mathrm{NP}_{n} \mathrm{EO}(0-18)$ 


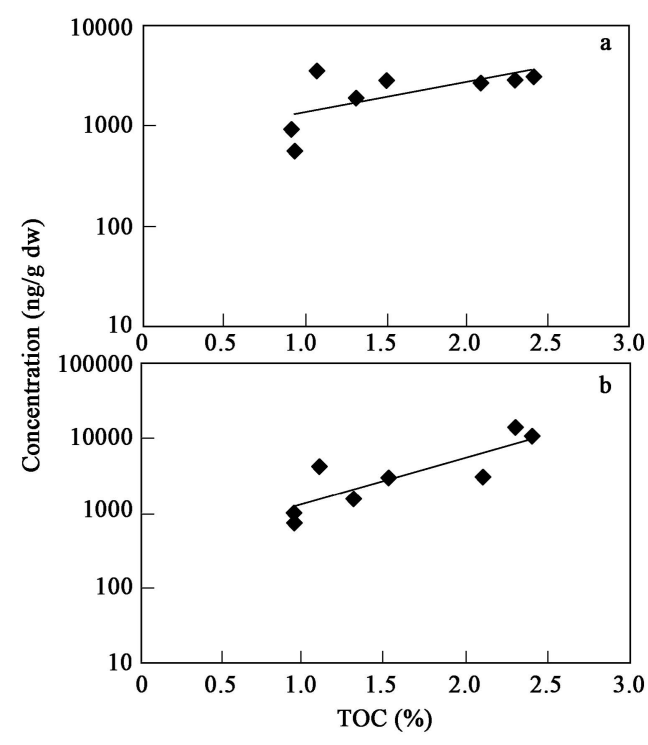

Fig. 5 Relationship between NP and NPEOs concentrations and TOC in the sedimentary core from Beipaiming Channel. (a) NP $(p<0.001$, $\left.r^{2}=0.4143\right)$; (b) NPEOs $\left(p<0.001, r^{2}=0.71\right)$.

core indicated that the channel received some effluents from STPs, and the sewage treatment ratio is relatively low in this area.

\section{References}

Ahel M, Giger W, 1993. Partitioning of alkylphenols and alkylphenol polyethoxylates between water and organicsolvents[J]. Chemosphere, 26: 1471-1478.

Ahel M, Giger W, Koch M, 1994a. Behavior of alkylphenol polyethoxylate surfactants in the aquatic environment-I. Occurrence and transformation in sewage treatment[J]. Water Res, 28: 1131-1142.

Ahel M, Giger W, Schaffner C, 1994b. Behavior of alkylphenol polyethoxylate surfactants in the aquatic environment-II. Occurrence and transformation in sewage treatment[J]. Water Res, 28: 1143-1152.

Ahel M, Molnar E, Ibric S et al., 2000. Estrogenic metabolites of alkylphenol polyethoxylates in secondary sewage effluents and rivers[J]. Water Sci Technol, 42: 15-22.

Ferrara F, Fabietti F, Delise M et al., 2001. Alkylphenolic compounds in edible molluscs of the Adriatic Sea (Italy)[J]. Environ Sci Technol, 35: 3109-3112.

Ferguson P L, Bopp R F, Chillrud S N et al., 2003. Biogeochemistry of nonylphenol ethoxylates in urban estuarine sediments[J]. Environ Sci Technol, 37: 3499-3506.

Giger W, Brunner P H, 1984. 4-Nonylphenol in sewage-sludge accumulation of toxic metabolites from nonionic surfac-

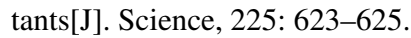

Gray M A, Metcalfe C D, 1997. Induction of testis-ova in Japanese medaka (Oryzias latipes) exposed to $p$ nonylphenol[J]. Environ Toxicol Chem, 16: 1082-1086.

Hu J, Wan Y, Shao B et al., 2005. Occurrence of trace organic contaminants in Bohai Bay and its adjacent Nanpaiwu River, north China[J]. Marine Chemistry, 95: 1-13.

Jobling S, Sheahan D, Osborn J A et al., 1996. Inhibition of testicular growth in rainbow trout (Oncorhynchus mykiss) exposed to estrogenic alkylphenolic chemicals[J]. Environ Toxicol Chem, 15: 194-202.

Jonkers N, Laane W P N R, Voogt P D, 2003. Fate of nonylphenol ethoxylates and their metabolites in two Dutch estuaries: evidence of biodegradation in the field[J]. Environ Sci Technol, 37: 321-327.

Kannan K, Keith T L, Nalor C G et al., 2003. Nonylphenol and nonylphenol ethoxylates in fish, sediment, and water from the Kalamazoo River, Michigan[J]. Arch Envirn Contam Toxicol, 44: 77-82.

Keith T L, Snyder S A, Naylor C et al., 2001. Identification and quantitation of nonylphenol ethoxylates and nonylphenol in fish tissues from Michigan[J]. Environ Sci Technol, 35: 1013.

Kvestak R, Ahel M, 1995. Biotransformation of nonylphenol polyethoxylate surfactants by estuarine mixed bacterial cultures[J]. Arch Environ Contam Toxicol, 29: 551-556.

Lye C M, Frid C L J, Gill M E et al., 2001. Estrogenic alkylphenols in fish tissues, sediments, and waters from the U.K. Tyne and Tees Estuaries[J]. Environ Sci Technol, 33: 1009-1014.

Maruyama K, Yuan M, Otsuki A, 2000. Seasonal changes in ethylene oxide chain length of poly(oxyethylene)alkylphenyl ether nonionic surfactants in three main rivers in Tokyo[J]. Environ Sci Technol, 34: 343-348.

Naylor C G, 1996. Proceedings of the CESIO 4th world surfactant congress. Barcelona, Spain; European committee on surfactants and detergents[C]. Brussels, Belgium. 378-391.

Rice C P, Schmitz-Afonso I, Loyo-Rosales J E et al., 2003. Alkylphenol and alkylphenol ethoxylates in carp, water, and sediment from the Cuyahoga River, Ohio[J]. Environ Sci Technol, 37: 3747-3754.

Servos M R, 1999. Review of the aquatic toxicity, estrogenic responses and bioaccumulation of alkylphenols and alkylphenol polyethoxylates[J]. Water Qual Res J Can, 34: 123-177.

Shang D Y, Macdonald R W, Ikonomou M G, 1999. Persistence of nonylphenol ethoxylate surfactants and their primary degradation products in sediments from near a municipal outfall in the strait of Georgia, British Columbia, Canada[J]. Environ Sci Technol, 33(9): 1366-1372.

Shao B, Hu J, Yang M, 2002. Determination of nonylphenol ethoxylates in the aquatic environment by normal phase liquid chromatography-electrospray mass spectrometry[J]. J Chromatog A, 950: 167-174.

Shao B, Hu J, Yang M et al., 2005. Nonylphenol and nonylphenol ethoxylates in river water, drinking water and fish tissues in the area of Chongqing, China[J]. Arch Environ Contam Toxicol, 48: 467-473.

Sharpe R M, Fisher J S, Millar M M et al., 1995. Gestational and lactational exposure of rats to xenoestrogens results in reduced testicular size and sperm production[J]. Environ Health Perspect, 103: 1136-1143.

Voogt P D, Beer K D, Vander W F, 1997. Determination of alkylphenol ethoxylates in industrial and environmental samples[J]. Tr Anal Chem, 16: 584-595.

Warhurst A M, 1995. An environmental assessment of alkylphenol ethoxylates and alkylphenols[Z]. Friends of the Earth Scotland, Edinburgh, Scotland.

White R, Jobling S, Hoare S A et al., 1994. Environmentally persistent alkylphenolic compounds are estrogenic[J]. Endocrinology, 135: 175-182.

Yamashita N, Kanna K, Imagawa T et al., 2000. Vertical profile of polychlorinated dibenzo- $p$-dioxins, dibenzofurans, naphthalenes, biphenyls, polycyclic aromatic hydrocarbons, and alkylphenols in a sediment core from Tokyo Bay, Japan[J]. Environ Sci Technol, 34: 3560-3567. 